\title{
Chapter 21 \\ Münster: How Prevention Visits Improve Local Child Protection
}

\author{
Andrea Walter and Danielle Gluns
}

\subsection{Münster-City Context and the Field of Local Childcare Policy}

Münster has around 300,000 inhabitants and is located in the biggest German state. It is a relatively wealthy city (compared to other cities in North Rhine-Westphalia) and can be characterised by a rather young (with around 50,000 students) and welleducated population with low unemployment rates. Its economy is dominated by a strong tertiary sector with a large spectrum of both public and church administrations, university and other higher education, science, healthcare, communication, insurances and financial institutions. Therefore, Münster has not been hit as hard by economic crises as other cities.

Social policy in Münster is influenced by a strong Catholic tradition, which leads to an emphasis on solidarity and subsidiarity and a connection to the concept of communitarianism (Vorländer 2001). Consequently, society has the duty to care for those who are not able to do so for themselves, whereas the smallest possible entity (the individual, the community etc.) should be responsible in order to avoid unnecessary collectivisation (Leuninger 2002, pp. 21-26). The foundation for this claim lies in the high value of personal autonomy in the Catholic tradition (Focke 1978, p. 192; Leuninger 2002, pp. 20f). Thus, the state should enable everyone to contribute actively to the society which stresses the social political focus on prevention and investments in human capital as a basis for competitiveness and participation (Leuninger 2002, pp. 113-116, 121).

These traditions are mirrored in local childcare policy, of which the prevention visits (see below) form a part. In this field, German municipalities have been a

\footnotetext{
A. Walter $(\bowtie) \cdot$ D. Gluns

Institute of Political Science, Westfälische Wilhelms-Universität Münster,

Scharnhorststr. 100, 48151 Münster, Germany

e-mail: andrea.walter@uni-muenster.de

D. Gluns

e-mail: d.gluns@uni-muenster.de

(C) The Author(s) 2016

T. Brandsen et al. (eds.), Social Innovations in the Urban Context,

Nonprofit and Civil Society Studies, DOI 10.1007/978-3-319-21551-8 21
} 
driving force for a long time. Making the reconciliation of work and family life possible for well-educated women has been the main objective in Münster. This aim is in line with the national legal requirement to increase the number of places in childcare for the under 3-year-olds. To sum it up, adequate supply of childcare facilities and more flexibility as well as increasing quality standards are seen as important for the individual wellbeing of families as well as for improving the attractiveness of the whole city. All in all, a broad consensus among the relevant actors from local politics and public administration as well as from organised civil society about promoting childcare policy can be identified. Concretely, the welfare associations and other stakeholders such as parents' initiatives are strongly involved. The main cleavage in this field regards promoters of affordability and accessibility on the one hand and promoters of high-quality care on the other, while there is agreement on the overall need for a high amount of institutional childcare.

\subsection{Internal Characteristics of the Prevention Visits ${ }^{1}$}

\subsubsection{Improving Local Child Protection by Assisting Every Family_Goals and Ways of Addressing Users}

The prevention visits are a new kind of service in the field of childcare policy and were initiated by the Youth Office in 2008. The Youth Office in Germany is responsible for child protection ( $§ 1$ Abs. 3 S.3 SGB VIII). For this aim, the office can intervene in families where the wellbeing of the children is threatened and can, as a last resort, decide to take children out of their families. Due to this, the Youth Office has a negative reputation in Germany, which is aggravated by the role of the Youth Office during the Third Reich and in the German Democratic Republic. With its staff of around 1,400 employees, the Youth Office in Münster is the largest administrative unit within the municipality (Youth Office Münster 2012, p. 163).

The general proceeding of the innovation is that all parents in Münster with a newborn child receive a visit from Youth Office employees. ${ }^{2}$ From a practical point of view, these prevention visits aim to assist parents with their children's upbringing. From a political point of view, these visits serve as an operative instrument to improve local child protection based on intensive and early family contact. Concretely, the responsible local authorities hope to improve the relationship between families and the Youth Office (improving the office's image) as well as to prevent worst-case scenarios like abuse or neglect of children or even infanticide. The local media coverage in June 2008 especially focused on the cases of 5-year-old Lea Sophie from Schwerin and 2-year-old Kevin from Bremen. Both died a horrible death

\footnotetext{
${ }^{1}$ Methodically, this chapter is mainly based on two expert interviews with representatives from the youth office, annual reports of the office as well as local newspaper articles.

${ }^{2}$ All facts about the family visits in the following subchapters without any designated sources are based on the newspaper article "Jugendamt will jedes Baby besuchen" (05/06/2008) as well as the website of the Youth Office.
} 
caused by child neglect (WN 05/06/2008). The implementation of the prevention visits was an initiative by the Youth Office itself. The concept of these visits is oriented at the so-called Dormagener Modell ${ }^{3}$ of prevention visits that was developed in the city of Dormagen in 2006. The actors of the Youth Office adapted the concept to the situation in Münster. A specific aspect of this Münster model is that the prevention team who is responsible for coordinating and realising these visits aims to visit every family in Münster, not only socially disadvantaged ones from poorer areas as it is done in other cities. The participation in the family visits is voluntary for the parents.

The innovation works in the following way: First of all, each family with a newborn child (these are about 2,400 per year in Münster) gets a letter of inquiry by the Youth Office. If they do not object, they receive a second letter in which the prevention team suggests an appointment. The concept offers different services: First of all, the prevention team informs the parents in an individual way about different issues relevant to parents: parental benefits, childcare facilities and preventive healthcare offers. In this context, the families get information leaflets, which are in line with the respective nationality of their child and the district of the parents' home. If desired by parents, a midwife accompanies the visits. Furthermore, the first parents' letter (Elternbriefe) is handed over to the families personally. These letters present, in total, 46 educational assistances (i.e. advice on breastfeeding or protective vaccination) and their dispatch to the families is staggered over the period from the first month of life up to the eighth birthday of the child. ${ }^{4}$ The parents' letters are conceptualised by the working group Neue Erziehung e.V. which is a nationally organised non-governmental organisation (NGO). ${ }^{5}$ They are available in many other municipalities, but not every Youth Office sends them to the families for such an extended period. As mentioned above, one of the main goals of these prevention visits is to ameliorate the negative image of the Youth Office which is amplified by the supra-regional media. ${ }^{6}$ To underline this aim, every child gets a welcome gift from the Youth Office. This toy symbolises that the prevention team does not want to take the children away from their parents, rather it wants to bring all families real benefit. The parents should get the impression that the Youth Office might be useful for every family member and in every (difficult) situation. The families should realise that they can rely on the Youth Office as a service provider. Ergo, these prevention visits are seen as a sort of door-opener ${ }^{7}$ by the employees of the Youth Office.

\footnotetext{
${ }^{3}$ The so-called Dormagener Modell is the title of a local programme, which aimed to develop instruments for preventing child abuse and intra-family violence. This pilot project was developed in the German municipality Dormagen in 2006. Many other municipalities were convinced of this new concept and adapted this model. See source "Dormagener Modell".

${ }^{4}$ The description of the parents' letters is based on the website of the Youth Office.

${ }^{5}$ The working group Neue Erziehung e.V. was founded in 1946 by teachers in Berlin. After the period of inhuman National Socialist and fascist tyranny, the members of this NGO aim to develop a new conversational understanding of education. Source: Website of Arbeitskreis Neue Erziehung.

${ }^{6}$ Interview with a representative of the Family Office.

${ }^{7}$ Interview with a representative of the Family Office.
} 


\subsubsection{Internal Organisation and Modes of Working}

The prevention team is composed of six qualified employees working part-time who coordinate and implement the appointments and visits. Every member is an employee of the Youth Office. This underlines the main purpose of the prevention team that its members should serve as ambassadors for the office. Volunteers, as in other German municipalities, would not have direct access to the services of the Youth Office. ${ }^{8}$ That is one of the reasons why the Youth Office decided to integrate the visits into the office itself. Each of the six employees should care for about 400 newborn children per year. Actually in the year 2009, 2069 families were visited. The visits are financially sustainable since they are funded as part of the annual budget.

\subsubsection{Context of the Innovation-Interaction with the Local Welfare System}

The prevention visits were initiated by the head of the Youth Office itself, who is one of the key players within the elite network of the city. As head of the office, she is a member of different administrative and local political networks (round tables, working groups etc.). Despite her network position, at the beginning, she had difficulties in finding political majorities for this program. Many politicians did not want the prevention team to visit families living in wealthy social environments as well. But the head of the Youth Office refused to accept any compromise and underlined that child protection is a universal issue concerning every family. ${ }^{9}$ The office aimed to achieve public consensus by arguing to prevent worst-case scenarios which are built up by media, politics and society. At the same time, they emphasized the supportive function of the visits as opposed to controlling families. Finally, this strategy succeeded. The political factions agreed. Today, the Youth Office is very satisfied with this innovation. The head of the Youth Office highlights its success and importance for the strategy of the Youth Office. ${ }^{10}$ This is also acknowledged by the local media. ${ }^{11}$

The high number of prevention visits which have been carried out over the last years $(2009: 2,069,2010: 2,314,2011: 2,080)$ shows the high demand as regards the prevention visits by families. In a quarter of those prevention visits in 2010 (497), the Youth Office identified a high need for advice, information as well as support. In more than 1000 cases, the prevention team informed parents about the offers of local services focusing on childcare (Youth Office Münster 2012, p. 87). In this way, the prevention visits have contributed to the intended image change of the Youth Office: from a control instance to a kind of service provider.

\footnotetext{
${ }^{8}$ Interview with the head of the Youth Office.

${ }^{9}$ Interview with the head of the Youth Office.

${ }^{10}$ Interview with the head of the Youth Office.

11 “Reicht ein Besuch?" a comment of the local journalist Karin Völker in WN 05/06/08.
} 
For evaluation, Münster takes part in an empirical study about German municipalities, which have introduced the instrument of prevention visits. With reference to the first results of the participating municipalities as well as the high demand of this instrument by municipalities in North-Rhine Westphalia, the empirical study evaluates the instrument of prevention visits positively and sees it on the path towards a regular offer (Regelangebot) (Frese and Günther 2012, p. 251). In addition to this, the evaluation of prevention visits in different cities underlines the positive effects of the specific Münster model: Parents participating in the study emphasise the positive effects of both working with employees of the Youth Office as well as visiting all parents in the city (Frese and Günther 2012).

\subsection{Conclusion}

The prevention visits can be seen as an important instrument in the process of image changing and improving child protection in Münster. The deep impact of this social innovation for the local welfare system can be explained by the following three context factors:

Being Part of the Prevention Approach as well as of the Local City Strategy This innovation supports the core value of prevention and especially the prevention program of the Youth Office. Furthermore, with their customer focus, these prevention visits help to improve the Youth Office's image as well as to strengthen the field of local childcare policy identified by the local elites as an important factor for the city to become more attractive for young families. Thus, this social innovation became an important pillar for the urban local welfare policy strategy.

Being an Integrated Part of the Local Welfare System Since its implementation five years ago, the instrument of the prevention visits has become firmly institutionalised within the field of local welfare politics in Münster. This is apparent in the merger of the prenatal advice and the prevention team in 2010. In June 2011, the unit "Prenatal advice, prevention services and family visits" was founded. This enables better networking between early services and the expansion of existing cooperative governance structures (Youth Office Münster 2012, p. 85). Furthermore, the visits are institutionalised in a financially sustainable way.

The Impact of the Local Network Governance for This Innovation A change in the welfare governance architecture can be identified. Local welfare policy in Münster seems to work more and more in networks as opposed to operating in a hierarchical process. This is underlined by the implementation process of the prevention visits, which was led by the highly embedded and active head of the Youth Office. Because of its new understanding as a customer-oriented institution, the Youth Office increasingly acts as a partner for civil society (families), not as a hierarchical instance. The negative reactions in the beginning have shown that local politics and civil society still perceived the Youth Office as an intervention authority 
(Ordnungs-/Eingriffsinstanz). The new governance forms offer some advantages for the success of this innovation: Problems and challenges (like financial issues) can be directly discussed between the involved actors. Solutions can be developed together before disagreement results in unbridgeable differences.

The analysis of the prevention visits in Münster demonstrates the necessity of innovators to connect to locally prevalent norms and values. The local welfare system not only structurally, but also "culturally" determines opportunities and obstacles for social innovations. Furthermore, the successful implementation of prevention visits in a given local context will depend on an active "policy entrepreneur" who can mobilize supporters and resources. ${ }^{12}$

Open Access This chapter is distributed under the terms of the Creative Commons AttributionNonCommercial 4.0 International License (http://creativecommons.org/licenses/by-nc/4.0/), which permits any noncommercial use, duplication, adaptation, distribution and reproduction in any medium or format, as long as you give appropriate credit to the original author(s) and the source, a link is provided to the Creative Commons license and any changes made are indicated.

The images or other third party material in this chapter are included in the work's Creative Commons license, unless indicated otherwise in the credit line; if such material is not included in the work's Creative Commons license and the respective action is not permitted by statutory regulation, users will need to obtain permission from the license holder to duplicate, adapt or reproduce the material.

\section{References}

Focke, F. (1978). Sozialismus aus christlicher Verantwortung - die Idee eines christlichen Sozialismus in

der katholisch-sozialen Bewegung und in der CDU. Wuppertal.

Frese, D., Günther, C. (2012). Praxisentwicklungsprojekt: "Aufsuchende Elternkontakte. Konzeptionen, Zugänge und Wirkungen. ” Präsentation der Ergebnisse auf der Abschlusstagung am 17. April 2012 im Wissenschaftspark Gelsenkirchen, Institut für soziale Arbeit e.V.

http://www.isa-muenster.de/cms/upload/pdf/tagungsdokumentation/abschluss_aufsuchende_elternkontakte/ISA_Ergebnisse_Tagung_17.04.pdf. Accessed 26 Feb 2013.

Leuninger, E. (2002). Gerechtigkeit schafft Frieden-Ein Kurs zur Einführung in die Katholische Soziallehre. Katholische Arbeitnehmer-Bewegung, Diözesanverband Limburg e.V., KAB-Bildungswerk Diözesanverband Limburg, 3. Einheit. http://www.kath-soziallehre.de. Accessed $20 \mathrm{Feb} 2013$.

Vorländer, H. (2001). Dritter Weg und Kommunitarismus. Aus Politik und Zeitgeschichte (pp. 16$17,16-23)$.

Youth Office Münster. (2011). Yearbook of the Youth Office 2010.

Youth Office Münster. (2012). Yearbook of the Youth Office 2011.

\footnotetext{
${ }^{12}$ A more elaborate development of the concept of policy entrepreneurs and their role for the initiation and implementation of social innovations has been published in Gluns, D., Walter, A. (2014). Wie Policy Entrepreneure soziale Innovationen umsetzen. Zwei Fallbeispiele aus der Kommune. In: Forschungsjournal Soziale Bewegungen, 2, Stadt—Ort sozialer Innovation. 69-79.
} 


\section{Newspaper Articles}

Jugendamt will jedes Baby besuchen. Westfälische Nachrichten WN—online edition, 6 June 2008.

\section{Interviews}

Representatives of the Family Office.

Head of the Youth Office.

\section{Internet}

Source "Dormagener Modell". http://www.dormagen.de/familiennetzwerk.html. Accessed 07 Jan 2014.

http://www.muenster.de/stadt/jugendamt/e_familienbuero.html. Accessed 07 Jan 2014. 